\title{
Ekstrak Daun Moringa oleifera terhadap Jumlah Folikel Tikus Model Sindroma Ovarium Polikistik
}

\author{
Dessy Amelia*1, Budi Santoso $^{2}$, Bambang Purwanto ${ }^{3}$ \\ ${ }^{1}$ Mahasiswa Magister Program Studi Ilmu Kesehatan Reproduksi Fakultas Kedokteran \\ Universitas Airlangga; Jalan Mayjen.Prof.Dr.Moestopo no.47 Surabaya, telp. 031-5030251, \\ fax:031-5022472 \\ ${ }^{2}$ Departemen Obstetri dan Ginekologi Fakultas Kedokteran-Rumah Sakit Dr.Soetomo \\ Universitas Airlangga; Jalan Mayjend Prof. Dr. Moestopo No. 6 - 8 Surabaya, telp. 031- \\ 5501078, fax: 031-5022472 \\ ${ }^{3}$ Departemen Fisiologi Fakultas Kedokteran Universitas Airlangga; Jalan \\ Mayjen.Prof.Dr.Moestopo no.47 Surabaya, telp. 031-5030251, fax:031-5022472
}

e-mail: ${ }^{1}$ dessyamelia99@gmail.com,${ }^{2}$ prof.budisantoso.apji@gmail.com,${ }^{3}$ bpoifo@gmail.com

\begin{abstract}
Abstrak
Sindroma Ovarium Polikistik (SOPK) adalah gangguan endokrin-metabolik yang memberi konsekuensi berat untuk kesehatan wanita, termasuk paling banyak menyebabkan infertilitas. Resistensi insulin merupakan kelainan metabolik yang paling umum pada SOPK. Moringa oleifera terbukti dapat meningkatkan ekspresi insulin dan menurunkan derajat pada diabetes mellitus, sehingga hal ini memungkinkan dapat meningkatkan jumlah folikel pada tikus betina model SOP-resistensi insulin. Tujuan penelitan untuk mengetahui pengaruh ekstrak daun Moringa oleifera dalam berbagai dosis dapat meningkatkan jumlah folikel pada tikus betina model SOPK-resistensi insulin. Metode penelitian menggunakan tikus putih strain Wistar (Rattus norvegicus) 100-130 gram yang dibagi menjadi lima kelompok, yaitu kontrol normal, kontrol SOPK-resistensi insulin, SOPK-resistensi insulin diberi metformin, SOPK-resistensi insulin diberi ekstrak daun Moringa oleifera $250 \mathrm{mg} / \mathrm{kgBB}$ dan 500 $m g / k g B B$. Model SPOK-resistensi insulin dibuat dengan menginjeksi testoteron propionat selama 28 hari, setelah itu dilanjutkan pengobatan selama 14 hari. Penelitian ini menganalisis jumlah folikel pada ovarium tikus. Hasil penelitian menunjukkan kelompok kontrolSOPK-resistensi insulin menunjukkan penurunakan jumlah folikel secara signifikan dibandingkan dengan kelompok kontrol normal ( $p<0.05)$.Kelompok metfromin dan ekstrak daun Moringa oleifera menunjukkan peningkatan signifikan jumlah folikel dibandingkan dengan kelompok kontrol SOPK-resistensi insulin ( $p<0.05)$. Kesimpulan penelitian menunjukkan ekstrak daun Moringa oleifera meningkatkan jumlah folikel pada tikus betina model SOPK-resistensi insulin.
\end{abstract}

Kata kunci-sindroma ovarium polikistik, Moringa oleifera, jumlah folikel 


\begin{abstract}
Polycystic Ovary Syndrome (PCOS) is an endocrine-metabolic disorder that has severe consequences for women's health that including the most causing of infertility. Insulin resistance is a frequent metabolic disorder in PCOS. Moringa oleifera has been shown to increase insulin expression and decrease the degree of insulin in diabetes mellitus, therefore it is expected that Moringa oleifera could increase number of follicle in female PCOS-insulin resistant rats. We aimed to prove the effect of Moringa oleifera leaf extract in various doses might increase number of follicle in female PCOS-insulin resistant rats. The Methode used old white rat of Wistar strain (Rattus norvegicus) 100-130 grams were divided into five groups $(n=8)$ including normal control, PCOS-insulin resistance, PCOS-insulin resistance given metformin and PCOS-resistance insulin were given Moringa oleifera leaf extract in two doses. Then, the PCOS model-insulin resistance by injection of testosterone propionate for 28 days. After 14 days treatment, we analyzed number of follicle. PCOS- insulin resistance control group showed that a significant decrease number of follicle $(p<0.05)$ compared with normal control group. Treatment of Moringa oleifera leaf extract and metformin group significantly increased number of follicle compared to PCOS-insulin resistance control group $(p<0.05)$. The conclusion showed that Moringa oleifera could inscreased number of follicle in female PCOS-insulin resistance rats.
\end{abstract}

Keywords - Polycystic ovary syndrome, Moringa oleifera, number of follicle 


\section{PENDAHULUAN}

Polycystic Ovary Syndrome (PCOS) atau Sindroma Ovarium Polikistik (SOPK) adalah gangguan endokrin-metabolik yang memberi konsekuensi berat untuk kesehatan wanita, termasuk paling banyak menyebabkan infertilitas (Rojas et al., 2014). Sindroma ovarium polikistik terjadi pada wanita usia reproduksi, yaitu 6-10\% berdasarkan pada kriteria US National Institutes of Health (NIH) dan mencapai setinggi $15 \%$ dengan menggunakan Rotterdam criteria 2003 (Fauser et al., 2012). Menurut hasil National Health and Medical Research Council (NHMRC) tahun 2015, didapatkan prevalensi SOPK sebanyak 12-21\% wanita usia reproduksi di Australia berdasarkan ESHRE/ Rotterdam criteria 2003.

Sindroma ovarium polikistik (SOPK) merupakan gangguan heterogenesis, multifaktor, kompleks genetik dan endokrin (Rojas et al., 2014). SOPK berdasarkan ESHRE/ Rotterdam Criteria 2003 didiagnosis jika terdapat dua dari tiga kriteria berikut ini: ovarium polikistik, oligoovulasi/anovulasi atau bukti klinis atau biokimia dari hiperandrogenisme. Selain kriteria di atas, etiologi lain seperti Cushing Syndrome, androgen producing tumours dan congenital adrenal hyperplasia harus di singkirkan (Fauser et al., 2012).

Etiologi dan patogenesis secara pasti dari kelainan ini belum dapat dipastikan, namun pada beberapa penelitian selanjutnya disepakati kelainan ini dipengaruhi secara genetik melalui autosomal dominal mode of inheritance (terutama dari paternal origin) (El-Sharkawy, Abdelmotaleb, Aly, \& Kabel, 2014). Patogenesis SOPK meliputi sekresi gonadotropin yang abnormal, steroidogenesis yang abnormal, resistensi insulin, disregulasi p450c17, dan genetik (Rusnasari, 2005). Resistensi insulin (71\%) merupakan kelainan metabolik yang paling umum pada SOPK dengan kejadian sindrom metabolik (31,5\%) (Zeyneloglu \& Esinler, 2007).

Resistensi insulin didefinisikan sebagai ketidakmampuan tubuh untuk beradaptasi dengan asupan normal glukosa atau ketidakmampuan insulin menghasilkan efek fisiologis metabolik yang memadai bagi tubuh (Djuwantono, Tjahyadi, \& Ritonga, 2010). Resistensi insulin mengarah pada kompensasi hiperinsulinemia, meningkatkan produksi androgen di ovarium dengan meningkatkan frekuensi GnRH dan sekresi pulsasi LH. Insulin dan Insulin-Like Growth Factor-1 (IGF-I) bertanggung jawab mengganggu ovulasi. Insulin dan IGF-1 secara tidak langsung juga dapat meningkatkan kadar androgen dengan menurunkan produksi SHBG (Sex Hormone Binding Globulin) di hati dan menekan sintesis IGFBP-1 (Insulin Like Growth Factor Binding Protein-1) secara langsung, cepat, dan lengkap baik di hati dan ovarium sehingga level IGF-I, IGF-II, dan testosteron bebas meningkat. Hal ini meningkatkan resiko jangka panjang diabetes mellitus tipe 2 dan penyakit kardiovaskular (Rojas et al., 2014).

Pertumbuhan dan perkembangan folikel dikontrol oleh sistem kompleks yang melibatkan sumbu hipotalamus-hipofisaovarium. hormon gonadotropin mempunyai peran penting dalam kontrol tersebut (Siregar, Linggi, Riady, \& Armansyah, 2006). Hormon gonadotropin yang terlibat dalam kontrol folikulogenesis adalah FSH dan LH. Hormon FSH berfungsi menginisiasi pertumbuhan folikel, sedangkan LH berfungsi menstimulasi pertumbuhan dan rupturnya folikel (Siregar et al., 2006).

Ovarium adalah sumber utama dari androstenedion berlebihan dan testosteron pada wanita hiperandrogen. Ovarium memainkan peran utama hiperandrogenisme pada perempuan meskipun tidak eksklusif. Steroidogenesis dalam folikel ovarium dicapai melalui kerjasama antara sel teka dan granulosa. Sel teka adalah sumber eksklusif androstenedion pada perempuan. Enzim 17E-hidroksisteroid dehidrogenase yang expresinya didominasi dalam sel granulosa, hal itu karenakan banyak testosteron yang diproduksi di dalam sel granulosa. Terlepas dari tempat metabolisme androstenedion untuk testosteron, dimulainya produksi androgen di ovarium khusus pada sel teka (Magoffin, 2006).

Peningkatan daya tanggap pada kasus ovarium polikistik terhadap stimulasi gonadotropin menyiratkan bahwa kapasitas steroidogenik meningkat di teka interna. 
Penelitian in vitro mengkonfirmasi bahwa sel teka dari ovarium polikistik menghasilkan lebih banyak androgen baik tidak distimulasi ataupun distimulasi gonadotropin (Gilling-Smith et al,1994 at.(Magoffin, 2006), p204). Dengan demikian, jelas bahwa pada ovarium polikistik telah meningkatkan kapasitas untuk mensekresi androgen. Dua faktor utama yang mempengaruhi jumlah total androgen yang disekresi oleh ovarium yaitu, jumlah sel teka di ovarium dan kapasitas steroidogenik dari masing-masing sel teka (Magoffin, 2006).

Peningkatan produksi androgen telah ditunjukkan oleh studi genomik dan molekul menjadi abnormalitas aktivitas steroidogenesis intrinsik di SOPK di sel teka. Peningkatan LH dan kadar insulin memperkuat kelainan intrinsik pada steroidogenesis sel teka. Level FSH yang relatif menurun (berhubungan dengan level LH) dan faktor intraovarian juga mempengaruhi abnormalitas aktivitas steroidogenesis sel teka (Legro et al,2013; Nelson et al,1999 at.(Diamanti-Kandarakis, 2008), p2).

Penurunan steroidogenesis pada jaringan ovarium melalui insulin dan $\mathrm{LH}$ bekerja langsung meningkatkan konsentrasi intraseluler Cyclic adenosine monophosphate (cAMP) dengan mengaktifkan Acute steroidogenic regulatory protein (StAR) yang berpotensi pada aktivitas langsung steroidogenesis melalui penurunan aktivitas jalur Phosphoinositide 3-kinase (PI3K). Insulin dan LH juga bekerja langsung meningkatkan transkripsi reseptor Low-density lipoprotein cholesterol (LDL-C) di sel granulosa ovarium melalui peningkatan aktivitas pada jalur Protein kinase A (PKA) dan Mitogenactivated protein kinase (MAPK) serta penurunan PI3K. Selain itu, insulin juga meningkatkan regulasi aromatisasi di sel granulosa ovarium sehingga produksi androgen meningkat di sel teka ovarium (Rojas et al., 2014). Produksi androgen berlebih ini mengganggu folikulogenesis sehingga mengakibatkan gangguan menstruasi dan berkembangnya beberapa kista di ovarium (Diamanti-Kandarakis, 2008).
Gejala yang paling umum dari SOPK adalah gangguan menstruasi seperti oligomenore atau amenore, infertilitas, kadar hormon masculinizing yang tinggi yang dimanifestasikan melalui timbulnya jerawat dan hirsutisme, dan sindrom metabolik yang muncul sebagai kecenderungan obesitas sentral, serta gejala lain yang berhubungan dengan resistensi insulin. Serum insulin, resistensi insulin dan tingkat homocysteine yang lebih tinggi pada wanita dengan SOPK dibandingkan dengan wanita normal (Nafiye et al,2010; Pasquali \& Gambineri,2006; (Kabel, 2016), p2).

Pengobatan pada pasien SOPK dengan obesitas memiliki tujuan memperbaiki ovulasi, menurunkan kadar androgen, dan penurunan berat badan tetap menjadi prioritas utama. Metformin merupakan pengobatan line pertama SOPK obese. Metformin oral adalah biguanida yang terbukti sebagai terapi diabetes melitus tipe 2, antihiperglikemik yang bekerja dengan cara menghambat penyerapan glukosa hepatik, meningkatkan penyerapan glukosa perifer, mengurangi level insulin perifer, dan meningkatkan GLUT-4 sehingga konsentrasi insulin akan menurun dan diikuti oleh fenomena reduksi dari androgen dan $\mathrm{LH}$ serta peningkatan SHBG. Metformin juga bisa bekerja langsung di sel teka mengurangi produksi androgen (Homburg, 2003); (Santoso, 2010). Metformin berguna dalam kasus SOPK pada remaja karena selain menekan nafsu makan dan juga merangsang penurunan berat badan (Santoso, 2010). Efek samping pada obat ini menimbulkan gangguan saluran cerna, seperti mual, flatulensi, dan diare. Obat ini diekskresikan melalui ginjal dan risiko akumulasi metformin serta asidosis laktat akan meningkat jika terdapat gangguan ginjal (Huang et al., 2015). Pengobatan metformin mungkin tidak cocok sebagai pengobatan SOPK jangka panjang.

Terapi herbal menjadi salah satu pengobatan alternatif yang sedang dikembangkan di masyarakat luas, salah satunya adalah Moringa oleifera. Moringa oleifera merupakan tanaman yang berasal dari india, dapat tumbuh di setiap wilayah tropis dan subtropis dengan suhu sekitar 25$35^{\circ} \mathrm{C}$. Tanaman ini juga banyak ditemukan di Indonesia. Penelitian terbaru Moringa 
oleifera memiliki potensi sebagai antioksidan, antikanker, antiinflamasi, antidiabetik, dan sebagai agen antimikroba (Gopalakrishnan, Doriya, \& Kumar, 2016). Hasil fitokimiawi terhadap Moringa oleifera adalah polifenol besar, yaitu quercetin glucoside, rutin, kaempferol glucoside, dan chlorogenic acid di dalam tepung Moringa oleifera melalui analisis HPLC (Gupta et al., 2012). Flavonol quercetin ditemukan dengan konsentrasi yang tinggi pada daun Moringa oleifera (Gopalakrishnan et al., 2016). Menurut penelitian Rahmat (2009) daun Moringa oleifera pada sampel kering memiliki total flavonol dan flavone sebesar 473,33 mg/ 100g dengan kandungan quercetin sebesar $384,61 \mathrm{mg} / 100 \mathrm{~g}, 5,29$ $\mathrm{mg} / 100 \mathrm{~g}$ luteolin, dan $83,44 \mathrm{mg} / 100 \mathrm{~g}$ kaempferol (Rahmat, 2009).

Kandungan terbesar dalam daun Moringa oleifera adalah quercetin dikenal dengan 3,3',4',5,7-pentahydroxyflavone (nama kimia: 4H-1-benzopyran-4-one,2(3,4-dihydroxyphenyl)-3,5,7-trihydroxy-

flavone; rumus kimia: $\mathrm{C}_{15} \mathrm{H}_{10} \mathrm{O}_{7}$ ) (Wang et al., 2017). Quercetin merupakan salah satu flavonoid memiliki unsur bioaktif kuat, dengan efek radikal bebas, antiinflamasi, antikanker, antihiperlipidemia, dan antiplatelet (Juywiak et al,2005 at.Wang et $a l, 2016, \mathrm{p} 5)$. Penelitian terbaru menjelaskan quercetin juga ditemukan menghasilkan inhibin PI3K (Zhai et al,2012; Wang et al,2016, p2). Inhibin PI3K quercetin bekerja penurunan ekspresi gen CYP17A1 di sel teka yang mungkin bertanggung jawab menurunkan aktivasi 17a-hidroksilase yang memainkan peran penting pada SOPK. Quercetin juga berpotensi memberikan efek langsung pada target jalur steroidogenesis sel teka ovarium (Shah \& Patel, 2016).

Penelitian yang dilakukan Shah \& Patel (2016) yang bertujuan mengkaji pengaruh quercetin pada hewan coba model SOPK. Quercetin yang digunakan berasal dari produk inhibitor PI3K dengan dosis pemberian $150 \mathrm{mg} / \mathrm{KgBB}$. Pada penelitian tersebut didapatkan hasil quercetin signifikan menurunkan kadar insulin, kadar testosteron dan LH, serta profil lipid. Quercetin juga menurunkan berat ovarium dan uterus serta meningkatkan angka folikel normal dan korpus luteum pada pada hewan coba model SOPK.
Penelitian sebelumnya dengan tujuan untuk melihat pengaruh pemberian ekstrak etanol daun Moringa oleifera terhadap insulitis dan ekspresi insulin pankreas menunjukkan pemberian dosis 250 dan 500 $\mathrm{mg} / \mathrm{kgBB}$ menyebabkan ekspresi insulin lebih tinggi dan derajat insulitis lebih rendah dibandingkan kelompok kontrol (Sulistyorini, Johan, \& Djamiatun, 2015). Peneliti ingin melakukan penelitian tentang pengaruh pemberian Moringa oleifera dapat meningkatka jumlah folikel pada tikus betina model Sindroma Ovarium Polikistik yang sampai saat ini belum dibuktikan.

\section{METODE PENELITIAN 2.1 Rancangan Penelitian}

Rancangan penelitian true experiment dengan menggunakan rancangan Posttest Only Control Group Design. Pada awal penelitian dilakukan penghomogenan sampel penelitian. Subjek penelitian terhadap tikus dibagi dalam 5 kelompok dengan jumlah 8 ekor tiap kelompok yang dipilih secara acak, yaitu kelompok kontrol normal, kontrol SOPK-resistensi insulin, SOPK-resistensi insulin dengan metformin, dan SOPKresistensi insulin dengan ekstrak daun Moringa oleifera dengan dosis 250 $\mathrm{mg} / \mathrm{kgBB}$ dan $500 \mathrm{mg} / \mathrm{kgBB}$. Hewan coba yang digunakan pada penelitian ini dilakukan kriteria inklusi yaitu berjenis kelamin betina, berat badan 100-130 gram, sehat, beraktivitas dan tingkah laku normal. Kriteria eksklusi pada penelitian ini dilakukan bila ada kelainan anatomi yang tampak dan sedang bunting dan drop out jika tikus tidak mau makan atau mati dalam masa penelitian.

\subsection{Tempat dan Waktu Penelitian}

Penelitian ini dilakukan di Laboratorium Biokimia Fakultas Kedokteran Universitas Airlangga. Penelitian ini dilakukan selama bulan Juni- September 2017.

\subsection{Variabel Penelitian}

Variabel pada penelitian ini terdiri dari variabel bebas, variabel terikat, dan variabel terkendali. Variabel bebas, yaitu dosis ekstrak Moringa oleifera $250 \mathrm{mg} / \mathrm{kgBB}$ dan 500 
$\mathrm{mg} / \mathrm{kgBB}$. Variabel terikat, yaitu jumlah folikel. Variabel terkendali, yaitu jenis hewan coba, jenis kelamin hewan coba, berat badan hewan coba, pemeliharaan dan perawatan hewan coba, dan perlakuan hewan coba.

\subsection{Definisi Operasional Variabel}

a. Ekstrak daun Moringa oleifera adalah ekstrak daun Moringa oleifera yang diberikan dengan dosis berbeda pada tiap kelompok perlakukan, yaitu: 250 $\mathrm{mg} / \mathrm{kgBB}$ dan $500 \mathrm{mg} / \mathrm{kgBB}$.

b. Jumlah folikel adalah jumlah folikel pada ovarium yang ditandai dengan oosit yang dikelilingi oleh beberapa lapis sel.

\subsection{Prosedur Penelitian}

Penelitian ini menggunakan tikus wanita (Rattus norvegicus) mempunyai berat 100-130 gram yang diperoleh dari Biokimia Fakultas Kedokteran Universitas Airlangga. Pemeliharaan tikus dilakukan di dalam kandang plastik ukuran $50 \times 30 \mathrm{~cm}$ dengan alas sekam kayu yang diganti setiap 4 hari sekali, makanan dan minuman (nutrisi tikus betina), timbangan untuk menimbang berat badan tikus, testosteron propionat, spuit untuk injeksi testosteron propionat, sonde untuk memasukkan ekstrak Moringa oleifera, object glass dan penutupnya, pewarna giemsa, pewarna asam pikrat, spidol permanent, alat bedah, papan diseksi, dan mikroskop cahaya. Kandang kemudian diletakkan di ruangan berventilasi udara alami di Laboratorium Biokimia Fakultas Kedokteran Universitas Airlangga.

Hewan coba sebelum dilakukan penelitian diadaptasi sekaligus pemilihan hewan coba yang akan dijadikan sampel dengan ditimbang berat badannya dan diberi nomer pada punggungnya dengan asam pikrat di Laboratorium Biokimia Fakultas Kedokteran Universitas Airlangga selama 1 minggu.

Penelitian ini menggunakan 5 kelompok dengan 3 kelompok sebagai kontrol dan 2 kelompok sebagai perlakuan. Setiap kelompok terdiri atas 8 hewan coba. Kelompok kontrol terdiri dari kelompok kontrol negatif dan kelompok kontrol positif.
Kelompok kontrol normal diberikan aquades selama 14 hari. Kelompok kontrol positif I mendapatkan model SOPK-resistensi insulin dan aquades sebagai terapinya. Kelompok kontrol positif II yang mendapat model SOPK-resistensi diberi terapi dengan metformin $2 \mathrm{mg} / 100$ gramBB selama 14 hari. Kelompok perlakuan yang mendapatkan model SOPK-resistensi insulin diberi terapi dengan ektrak Moringa oleifera dengan dosis $250 \mathrm{mg} / \mathrm{kgBB}$ dan $500 \mathrm{mg} / \mathrm{kgBB}$ selama 14 hari.

\subsection{Pembuatan model SOPK-resistensi insulin}

Testosteron (merk Wonder, PT.Wonderindo Pharmatama, Jakarta, Indonesia) merupakan hormon yang digunakan untuk pembuatan model Sindroma Ovarium Polikistik (SOPK) pada penelitian ini, hormon ini dapat diberikan secara intramuskular atau subkutan di paha kiri dengan dosis $1 \mathrm{mg} / 100 \mathrm{grBB}$, volume yang dimasukkan ke setiap tikus adalah 0,1 cc/100grBB, diberikan $1 \mathrm{kali} / \mathrm{hari}$ selama 28 hari hingga model SOPK-resistensi insulin didapatkan. Swab vagina untuk mengetahui siklus apa yang sedang berlangsung sebelum pemberian testosteron. Siklus estrus adalah siklus yang diharapkan sebelumnya pemberian testosteron.

\subsection{Pemberian Ekstrak Daun Moringa oleifera}

Ekstrak Moringa oleifera yang dipakai dalam penelitian ini didapatkan dari Kelorina, PT. Moringa Organik Indonesia, semua proses dilakukan sesuai standar untuk mendapatkan ekstrak daun Moringa oleifera. Pemberian ekstrak daun Moringa oleifera dengan dosis $250 \mathrm{mg} / \mathrm{kgBB}$ dan 500 $\mathrm{mg} / \mathrm{kgBB}$ selama 14 hari dengan alat sonde. Volume yang diberikan untuk spesies rat sebesar $\quad 0,1-0,2 \mathrm{ml} / 10 \mathrm{~g}$ atau $1-2 \mathrm{ml} / 100 \mathrm{gr}$ (Handout Oral Gavage in Rodents University of Minnesota Driven to Discover Second Edition, 2014).

\subsection{Pengambilan Spesimen Ovarium}

Penghitungan jumlah folikel dilakukan pada tikus yang dibunuh dengan 
menggunakan teknik dislocatio os cervicalis (dislokasi pada leher). Kemudian tikus diposisikan pada papan bedah menggunakan pins dan dibedah mulai dari bagian perut atau uterus dengan menggunakan guntung bengkok. Organ ovarium diambil dan dipisahkan menggunakan gunting lurus kemudian dibersihkan bagian lemak yang masih menempel. Organ dicuci dengan aquades hingga bersih dari darah kemudian dicuci dengan $\mathrm{NaCl} 0,9 \%$ berulang-ulang. Organ diamati secara makroskopik dan dicatat perubahan yang ditemukan. Organ ditiriskan di atas kertas saring setelah air berkurang dilakukan penimbangan dengan organ diletakkan pada cawan petri kering kemudian dicatat beratnya masing-masing pada kertas blangko. Selanjutnya organ dimasukkan dalam pot berisi formalin 4$10 \%$ dan buffer formalin.

\subsection{Penghitungan jumlah folikel}

jumlah folikel dengan menggunakan pewarnaan HE (Hematoxylin-Eosin). HE adalah metode pewarnaan yang banyak digunakan dalam pewarnaan jaringan sehingga diperlukan dalam penelitian ini.

\subsection{Pengolahan dan Analisis Data}

Analisis deskriptif dilakukan pada semua data variabel penelitian untuk memperoleh rerata dan simpang bakunya. Data yang diperoleh dilakukan uji analisis statistik menggunakan program SPSS versi 18.0 (SPSS,Inc., Chicago,IL). Hasil penelitian dianalisis secara statistik untuk mengetahui uji normalitas menggunakan uji Shapiro-wilk. Jika data berdistribusi normal dilanjutkan dengan analisis ANOVA. Sedangkan jika salah satu kelompok data tidak homogen atau tidak berdistribusi normal, maka digunakan uji non-parametrik uji Krukal Wallis. Nilai signifikan dalam penelitian ini apabila variabel yang dianalisis memiliki $\mathrm{P}<0,05$.

\subsection{Ethical Clearance}

Adapun protokol penelitian ini akan dilakukan oleh komite etik Fakultas Kedokteran Hewan Universitas Airlangga melalui uji etik.

\section{HASIL DAN PEMBAHASAN}

Hewan coba pada penelitian ini adalah tikus betina Rattus nervegicus berusia 3 bulan yang mendapatkan perawatan selama penelitian di Laboratorium Biokimia Fakultas Kedokteran Universitas Airlangga Surabaya. Hasil swab vagina pada hewan coba sebelum dilakukan penelitian menunjukkan siklus estrus. Ini sesuai dengan siklus yang diharapkan sebelum dilakukan perlakuan, dalam penelitian ini perlakuan dengan memberikan injeksi testosteron propionat untuk model SOPK-resistensi insulin. Selain itu, ini menunjukkan bahwa hewan coba yang akan dilakukan menelitian menunjukkan memiliki reproduksi yang sehat. Pemeriksaan swab vagina dilakukan di Laboratorium Institute of Tropical Disease (ITD) Universitas Airlangga

Hasil pengukuran selisih berat badan tikus betina Rattus nervegicus sebelum dan sesudah perlakuan dapat dilihat pada Tabel 1.

Tabel 1. Pengukuran pertambahan berat badan tikus betina Rattus nervegicus sebelum dan sesudah perlakuan

\begin{tabular}{llc}
\hline \multicolumn{1}{c}{ Kelompok } & Jumlah folikel \\
\hline K1 & Kontrol normal & $58.75 \pm 14.17$ \\
& Kontrol SOPK-resistensi & $74 \pm 18.28^{\mathrm{a}}$ \\
K2 & insulin \\
K3 & $\begin{array}{l}\text { Kontrol SOPK-resistensi } \\
\text { insulin dengan Metformin }\end{array}$ & $77 \pm 12.17^{\mathrm{a}}$ \\
K4 $\begin{array}{l}\text { SOPK-resistensi insulin } \\
\text { dengan Moringa oleifera }\end{array}$ & $66.25 \pm 8.21$ \\
& \\
& 250 mg/kgBB \\
K5 $\begin{array}{l}\text { SOPK-resistensi insulin } \\
\text { dengan Moringa oleifera }\end{array}$ & $55.62 \pm 6.32^{\mathrm{b}}$ \\
& $500 \mathrm{mg} /$ kgBB \\
${ }^{\mathrm{a}}$ signifikan berbeda dari kontrol normal \\
$(\mathrm{p}<0.05)$
\end{tabular}

Berdasarkan tabel 1. menunjukkan bahwa berat badan tikus betina Rattus nervegicus sebelum dan sesudah perlakuan pada kelompok kontrol normal berbeda bermakna dengan kelompok kontrol SOPKresistensi insulin dan kelompok kontrol SOPK-resistensi insulin dengan diberikan metformin. Kelompok perlakuan SOPK- 
resistensi insulin yang diberikan ekstrak daun Moringa oleifera $500 \mathrm{mg} / \mathrm{kgBB}$ (K5) berbeda bermakna dengan kelompok kontrol SOPK-resistensi insulin sedangkan kelompok perlakuan lain tidak menunjukkan perbedaan yang bermakna.

Penghitungan secara histologi jumlah folikel pada ovarium kanan dan kiri tikus tikus betina Rattus norvrgicus di bawah mikroskop menggunakan mikrometer dapat dilihat pada tabel 2. di bawah ini.

Tabel 2. Pengaruh pemberian ekstrak daun Moringa oleifera terhadap jumlah folikel pada tikus betina model SOPK-Resistensi Insulin

\begin{tabular}{llc}
\hline \multicolumn{1}{c}{ Kelompok } & Jumlah folikel \\
\hline K1 & Kontrol normal & $25.12 \pm 3.18$ \\
& Kontrol SOPK-resistensi & $12.12 \pm 4.82^{\mathrm{a}}$ \\
K2 & insulin & \\
K3 $\begin{array}{l}\text { Kontrol SOPK-resistensi } \\
\text { insulin dengan Metformin }\end{array}$ & $25.37 \pm 2.20^{\mathrm{b}}$ \\
K4 $\begin{array}{l}\text { SOPK-resistensi insulin } \\
\text { dengan Moringa oleifera }\end{array}$ & $28.75 \pm 3.15^{\mathrm{b}}$ \\
& \\
K5 & $\begin{array}{l}\text { SOPK-resistensi insulin } \\
\text { SOngan Moringa oleifera }\end{array}$ & $27.75 \pm 4.17^{\mathrm{b}}$ \\
& \\
\hline & \\
\hline
\end{tabular}

${ }^{a}$ signifikan berbeda dari kontrol normal $(\mathrm{p}<0.05)$

${ }^{\mathrm{b}}$ signifikan berbeda dari kontrol SOPKresistensi insulin $(\mathrm{p}<0.05)$

Berdasarkan tabel 2. Menunjukkan bahwa jumlah folikel pada kelompok kontrol SOPK-resistensi insulin pada tikus betina yang dilakukan injeksi dengan testosteron propionat $1 \mathrm{mg} / 100$ gramBB selama 28 hari mengalami penurunan jumlah folikel secara signifikan dibandingkan dengan kelompok kontrol normal $(\mathrm{p}<0.05)$. Ini sesuai dengan penelitian model SOPK dapat dilakukan dengan pemberian testosteron propionat pad tikus betina, meliputi perubahan morfologi maupun gangguan hormonal sebagaimana SOPK pada manusia. Pemberian testosteron propionat dengan dosis $1 \mathrm{mg} / \mathrm{grBB}$ selama 14 hari akan didapatkan suatu keadaan yang menyerupai SOPK dengan ciri-ciri tidak didapatkan korpus luteum, adanya ovarium polikistik, hipertekosis pada stroma serta penipisan / atresia sel glukosa. Pemberian testosteron propionat selama 21 hari mulai didapatkan keadaan resistensi insulin dan pemberian testosteron propionat selama 28 hari memberikan hasil lebih bermakna terhadap keadaan resistensi insulin. Keadaan hiperandrogen dapat mempengaruhi indeks resistensi insulin serta kadar asam lemak bebas di serum. Semakin lama paparan androgen yang diberikan maka indeks resistensi insulin dan kadar asam lemak bebas akan meningkat (Muttaqin (2009); (Veterini, Santoso, \& Widjiati, 2015)). Penelitian ini menunjukkan bahwa pembuatan model SOPK-resistensi insulin yang dilakukan pada tikus betina yang diinjeksi testosteron propionat sebanyak 1 $\mathrm{mg} / 100 \mathrm{gBB}$ secara intra muskular selama 28 hari menunjukkan telah terjadi hiperinsulinemia dan terdapat suatu keadaan yang menyerupai SOPK dengan ciri-ciri tidak didapatkan korpus luteum. Peningkatan androgen dan asam lemak bebas akan menghambat ekskresi insulin di hepar dan pengangkutan glukosa di otot, serta akhirnya menyebabkan hiperinsulinemia dan resistensi insulin (Marshall, 2001); (Mukherjee \& Maitra, 2010).

Androgen secara langsung menghambat kerja insulin di perifer maupun di hepar, androgen secara tidak langsung juga mempengaruhi sensitifitas insulin dengan mengubah komposisi tubuh melalui metabolisme lemak (Volpi et al., 2005). Androgen (testosteron) menyebabkan resistensi insulin dengan menurunkan jumlah dan efektivitas protein pengangkut glukosa, khususnya glucose transporter type 4 (GLUT-4) yang bertanggung jawab terhadap pengangkutan glukosa di otot dan lemak. Testosteron memfasilitasi lipolisis dan pemecahan lemak abdomen, menyebabkan peningkatan asam lemak bebas. Peningkatan androgen dan asam lemak bebas akan menghambat ekskresi insulin di hepar dan pengangkutan glukosa di otot, serta akhirnya menyebabkan hiperinsulinemia dan resistensi insulin (Marshall, 2001);(Mukherjee \& Maitra, 2010).

Resistensi insulin merupakan suatu kondisi yang berhubungan dengan kegagalan organ target yang secara normal merespon aktivitas hormon insulin. Resistensi insulin mengarah pada kompensasi hiperinsulinemia, meningkatkan produksi androgen di ovarium dengan meningkatkan 
frekuensi GnRH dan sekresi pulsasi LH (Rojas et al., 2014). Peningkatan resistensi insulin pada perifer akan berakibat terhadap peningkatan serum insulin. Insulin dalam kadar tinggi ini akan berikatan dengan reseptor IGF-1, hal ini dikarenakan struktur dari reseptor IGF-1 mirip dengan struktur insulin. Insulin dan IGF-1 bertanggung jawab terhadap gangguan ovulasi. IGF-1 ini merangsang sel teka ovarium serta bersama dengan LH akan merangsang produksi androgen di ovarium. Insulin secara tidak langsung juga dapat meningkatkan kadar androgen dengan menurunkan produksi SHBG (Sex Hormone Binding Globulin) di hati dan IGFBP-1 (Insulin Like Growth Factor Binding Protein-1) dan dengan demikian meningkatkan testosteron bebas dan level IGF-1, IGF-2 (Balen, Conway, Homburg, \& Legro, 2005).

Pada konsentrasi tinggi, insulin sendiri mengaktivasi reseptor IGF-1 yang kemudian akan merangsang dibentuknya androgen di dalam ovarium. Peningkatan androstenedion sebagai akibat rangsangan IGF-1 akan meningkatkan produksi estron pada jaringan lemak, estron dengan estradiol bebas akan merangsang sekresi estrogen dimana estrogen memberikan rangsangan positif ke sentral, sehingga amplitudo dan frekuensi pulsasi GnRH meningkatkan produksi LH kemudian LH merangsang produksi androgen di ovarium (Balen et al., 2005).

Pada keadaan anovulasi yang terus menerus akan terjadi perubahan kadar hormon yang sebelumnya fluktuatif menjadi relatif menetap dengan kadar LH yang tinggi. Hal ini disebabkan oleh beberapa faktor, antara lain;

a. Meningkatnya sensitifitas hipotalamus terhadap stimulasi GnRH.

b. Meningkatkan frekuensi sekresi GnRH akibat penurunan tonus opioid yang berfungsi menghambat sekresi $\mathrm{GnRH}$ akibat tidak adanya progesteron dalam waktu yang lama.

c. Meningkatkan kadar estron akibat pembentukannya di jaringan perifer, sedangkan kadar FSH tetap rendah karena pengaruh penekanan oleh kadar estron yang tinggi (Balen et al., 2005).

Ovarium adalah sumber utama dari androstenedion berlebihan dan testosteron pada wanita hiperandrogen. Ovarium memainkan peran utama hiperandrogenisme pada perempuan meskipun tidak eksklusif. Steroidogenesis dalam folikel ovarium dicapai melalui kerjasama antara sel teka dan granulosa. Sel teka adalah sumber eksklusif androstenedion pada perempuan. Enzim 17E-hidroksisteroid dehidrogenase yang expresinya didominasi dalam sel granulosa, hal itu karenakan banyak testosteron yang diproduksi di dalam sel granulosa. Terlepas dari tempat metabolisme androstenedion untuk testosteron, dimulainya produksi androgen di ovarium khusus pada sel teka (Magoffin, 2006).

Peningkatan daya tanggap pada kasus ovarium polikistik terhadap stimulasi gonadotropin menyiratkan bahwa kapasitas steroidogenik meningkat di teka interna. Penelitian in vitro mengkonfirmasi bahwa sel teka dari ovarium polikistik menghasilkan lebih banyak androgen baik tidak distimulasi ataupun distimulasi gonadotropin (Gilling-Smith et al,1994 at.(Magoffin, 2006), p204). Dengan demikian, jelas bahwa pada ovarium polikistik telah meningkatkan kapasitas untuk mensekresi androgen. Dua faktor utama yang mempengaruhi jumlah total androgen yang disekresi oleh ovarium yaitu, jumlah sel teka di ovarium dan kapasitas steroidogenik dari masing-masing sel teka (Magoffin, 2006).

Peningkatan produksi androgen telah ditunjukkan oleh studi genomik dan molekul menjadi abnormalitas aktivitas steroidogenesis intrinsik di SOPK di sel teka. Peningkatan LH dan kadar insulin memperkuat kelainan intrinsik pada steroidogenesis sel teka. Level FSH yang relatif menurun (berhubungan dengan level LH) dan faktor intraovarian juga mempengaruhi abnormalitas aktivitas steroidogenesis sel teka (Legro et al,2013; Nelson et al,1999 at.(Diamanti-Kandarakis, 2008), p2).

Penurunan steroidogenesis pada jaringan ovarium melalui insulin dan $\mathrm{LH}$ bekerja langsung meningkatkan konsentrasi intraseluler Cyclic adenosine monophosphate (cAMP) dengan mengaktifkan Acute steroidogenic regulatory protein (StAR) yang berpotensi pada aktivitas langsung steroidogenesis 
melalui penurunan aktivitas jalur Phosphoinositide 3-kinase (PI3K). Insulin dan LH juga bekerja langsung meningkatkan transkripsi reseptor Low-density lipoprotein cholesterol (LDL-C) di sel granulosa ovarium melalui peningkatan aktivitas pada jalur Protein kinase A (PKA) dan Mitogenactivated protein kinase (MAPK) serta penurunan PI3K. Selain itu, insulin juga meningkatkan regulasi aromatisasi di sel granulosa ovarium sehingga produksi androgen meningkat di sel teka ovarium (Rojas et al., 2014).

Kadar LH meningkat akan menyebabkan sel teka yang aktif menghasilkan androgen dalam bentuk androstenedion dan testosteron. Keadaan hiperandrogen ini mengakibatkan lingkungan internal folikel bersifat dominan androgen sehingga tidak dapat berkembang dan menjadi atresia. Atresia pada folikel terutama berhubungan dengan degenerasi sel granulosa sementara sel teka masih dipertahankan. Sel teka masih aktif menghasilkan androgen akibat rangsangan LH, FSH, tidak secara total tersupresi (Balen et al., 2005).

Hasil penelitian yang ditunjukkan tabel 2. juga menjelaskan bahwa jumlah folikel antara kelompok kontrol normal dengan kelompok kontrol SOPK-resistensi yang diberi metformin dan kelompok perlakukan dengan ekstrak daun Moringa oleifera 250 $\mathrm{mg} / \mathrm{kgBB}$ dan $500 \mathrm{mg} / \mathrm{kgBB}$ tidak terdapat berbedaan bermakna. Ini menunjukkan bahwa kelompok perlakuan dengan ekstra daun Moringa oleifera dan metformin selama 14 hari secara umum dapat meningkatkan jumlah folikel mendekati normal setelah diberi perlakuan model SOPK-resistensi insulin yang dapat dibandingkan dengan kelompok kontrol normal.

Hasil penelitian ini juga menjelaskan bahwa kelompok kontrol SOPK-resistensi yang diberi metformin dan kelompok perlakukan dengan ekstrak daun Moringa oleifera $250 \mathrm{mg} / \mathrm{kgBB}$ dan $500 \mathrm{mg} / \mathrm{kgBB}$ menunjukkan peningkatan jumlah folikel secara signifikan dibandingkan dengan kelompok kontrol SOPK-resistensi insulin $(\mathrm{p}<0.05)$.

Moringa oleifera atau yang lebih dikenal dengan kelor awalnya banyak tumbuh di India, namun kini banyak ditemukan di daerah beriklim tropis (Grubben, 2004). Pada beberapa negara Moringa oleifera dikenal dengan sebutan benzolive, drumstick tree, kelor, marango, mlonge, mulangay,nebeday, saijhan, dan sajna (Fahey, 2005).

Moringaceae terdiri dari satu marga dengan beberapa jenis yaitu $M$. oleifera, $M$. arabica, M. pterygosperma, $M$. peregrine (Roloff et al,1789 at (Gopalakrishnan et al., 2016)). Daun sebesar ujung jari berbentuk bulat telur, tersusun majemuk dan gugur di musim kemarau, tinggi pohon mencapai 512 meter, bagian ujung membentuk payung, batang lurus (diameter 10-30 $\mathrm{cm}$ ) menggarpu, berbunga sepanjang tahun berwarna putih/krem, buah berwarna hijau muda, tipis dan lunak. Tumbuh subur mulai dataran rendah sampai ketinggian 700 meter diatas permukaan laut.

Penelitian terbaru Moringa oleifera memiliki potensi sebagai antioksidan, antikanker, antiinflamasi, antidiabetik, dan sebagai agen antimikroba (Gopalakrishnan et al., 2016). Moringa oleifera merupakan polifenol besar, yaitu quercetin glucoside, rutin, kaempferol glucoside, dan chlorogenic acid di dalam tepung Moringa oleifera melalui analisis HPLC (Gupta et al., 2012). Flavonol quercetin ditemukan dengan konsentrasi yang tinggi pada daun Moringa oleifera (Gopalakrishnan et al., 2016). Ini dapat dilihat pada kandungan flavonol dan flavone pada daun Moringa oleifera dengan perhitungan menggunakan eksternal standar memberikan hasil sebagai berikut : berdasarkan wet basis (per $100 \mathrm{~g}$ sampel segar), yaitu 1,38 mg luteolin, $101.94 \mathrm{mg}$ quarcetin, dan 21,05 $\mathrm{mg}$ kaempferol, sehingga totalnya adalah $124.37 \mathrm{mg}$. Konsentrasi flavonol dan flavones yang diperoleh berdasarkan dry basis (per $100 \mathrm{~g}$ sampel kering) adalah 5,53 $\mathrm{mg}$ luteolin, $409.06 \mathrm{mg}$ quarcetin, dan $84,48 \mathrm{mg}$ kaempferol sehingga totalnya adalah 499.07 $\mathrm{mg}$. Berdasarkan hasil yang diperoleh, daun Moringa oleifera memiliki kandungan flavonol dan flavones total yang cukup besar sebesar $473,33 \mathrm{mg} / 100 \mathrm{~g}$ yang didominasi kandungan quercetin sebesar $384,61 \mathrm{mg} /$ 100g (Rahmat, 2009).

Quercetin merupakan salah satu flavonoid memiliki unsur bioaktif kuat, 
dengan efek radikal bebas, antiinflamasi, antikanker, antihiperlipidemia, dan antiplatelet (Juywiak et al,2005 at.Wang et $a l, 2016$, p5). Selain itu, quersetin dikenal dengan 3,3',4',5,7-pentahydroxyflavone (nama kimia: 4H-1-benzopyran-4-one,2(3,4-dihydroxyphenyl)-3,5,7-trihydroxyflavone; rumus kimia: $\mathrm{C}_{15} \mathrm{H}_{10} \mathrm{O}_{7}$ ) (Wang et al,2016). Quercetin merupakan salah satu flavonoid memiliki unsur bioaktif kuat, dengan efek radikal bebas, antiinflamasi, antikanker, antihiperlipidemia, dan antiplatelet (Juywiak et al,2005 at.(Wang et al., 2017), p5). Penelitian terbaru menjelaskan quercetin juga ditemukan menghasilkan inhibin PI3K (Zhai et al,2012 at Wang et al,2016, p2). Quercetin berpotensi memberikan efek langsung pada target jalur steroidogenesis pada sel teka ovarium melalui inhibitor PI3K, menurunkan ekspresi gen CYP17A1 di sel teka yang bertanggung jawab pada penurunan aktivasi 17a-hidroksilase. Penurunan aktivasi 17a-hidroksilase ini berperan dalam sintesis steroid dengan menurunkan konversi progesteron ke androgen sehingga menurunkan kadar androgen(Rojas et al., 2014). Selain itu, melalui jalur PI3K dapat memfosforilasi protein Akt sehingga ketika protein Akt diaktifkan memainkan peran penting pada molekul GLUT4 dan fork-head box protein O1 (FOXO1) (Li \& Albertini, 2013) .

Glucose transporter type 4 (GLUT-4) adalah protein transpor untuk glukosa yang bertujuan membawa glukosa masuk ke dalam sel. Proses translokasi GLUT-4 ke permukaan sel target diawali dengan ikatan insulin dan reseptor insulin subunit $\alpha$ dimana ikatan tersebut menyebabkan subunit $\beta$ dari reseptor insulin dan subunit lain yaitu Insulin Reseptor Substrate-1 (IRS-1) mengadakan autofosforilasi. IRS-1 selanjutnya mengaktifkan Phosphoinositide 3-kinase (PI3K) yang memediasi translokasi GLUT-4 ke permukaan sel target (Shah \& Patel, 2016). Peningkatan translokasi GLUT-4 menyebabkan uptake glukosa dari ekstra sel ke dalam intra sel juga meningkat. Peningkatan uptake glukosa memperbaiki kondisi resistensi insulin.

Penurunan kadar insulin di jaringan perifer akan mengarah pada penurunan produksi androgen di ovarium. Penurunan kadar insulin dan IGF-1 secara tidak langsung juga dapat menurunkan kadar androgen dengan meningkatkan produksi SHBG (Sex Hormone Binding Globulin) di hati dan meningkatkan sintesis IGFBP-1 (Insiline Like Growth Factor Binding Protein-1) secara langsung, cepat, dan lengkap baik di hati dan ovarium sehingga level IGF-I, IGF-II, dan testosteron bebas menurun (Rojas et al., 2014). Penurunan androgen ini akan mempengaruhi lingkungan ovarium, gangguan sistem aromatisasi androgen menjadi estrogen yang memicu tidak terjadinya atresi folikel lebih dini. Penurunan resistensi insulin menurunkan frekuensi GnRH dan sekresi pulsasi LH sehingga terjadi perbaikan pada folikulogenesis (atresia dini tidak terjadi).

\section{KESIMPULAN DAN SARAN 4.1 Kesimpulan}

Pemberian ekstrak daun Moringa oleifera pada dosis $250 \mathrm{mg} / \mathrm{kgBB}$ dan 500 $\mathrm{mg} / \mathrm{kgBB}$ terbukti dapat meningkatkan jumlah folikel pada tikus betina model SOPK-resistensi insulin.

\subsection{Saran}

Penelitian SOPK dengan resistensi insulin melalui pemberian ekstrak daun Moringa oleifera terbukti dapat meningkatkan jumlah folikel pada tikus betina model SOPK-resistensi insulin. Penelitian pemberian ekstrak daun Moringa oleifera sebagai salah satu polifenol besar (quercetin) yang dapat digunakan untuk pilihan alternatif pengobatan SOPK perlu dilanjutkan dengan melihat duration of action dari efektifitas pemberian ekstrak daun Moringa oleifera pada pengobatan SOPK. Penelitian ini masih memiliki kekurangan pada kelompok kontrol negatif, hewan coba tidak diberikan injeksi pengganti testosteron propionat sehingga tingkat stress yang dialami berbeda dengan kelompok hewan coba model SOPKresistensi insulin dan belum dilakukan memisahkan zat toksik dengan mengambil zat yang efektif pada ekstrak daun kelor (moringa oleifera) bagi pengobatan SOPK .

\section{DAFTAR PUSTAKA}


Balen, A. H., Conway, G. S., Homburg, R., \& Legro, R. S. (2005). Polycystic ovary syndrome: a guide to clinical management: CRC Press.

Diamanti-Kandarakis, E. (2008). Polycystic ovarian syndrome: pathophysiology, molecular aspects and clinical implications. Expert Reviews in molecular medicine, 10.

Djuwantono, T., Tjahyadi, D., \& Ritonga, M. A. (2010). Isu Terkini Penanganan Yang Tepat Dampak Metabolik Sindroma Polikistik Ovarium. Universitas Padjadjaran.

El-Sharkawy, A. A., Abdelmotaleb, G. S., Aly, M. K., \& Kabel, A. M. (2014). Effect of metformin on sleep disorders in adolescent girls with polycystic ovarian syndrome. Journal of pediatric and adolescent gynecology, 27(6), 347-352.

Fahey, J. W. (2005). Moringa oleifera: A Review of the Medical Evidence for Its Nutritional, Therapeutic, and Prophylactic Properties. Part 1. Trees for life Journal, 1(5).

Fauser, B. C., Tarlatzis, B. C., Rebar, R. W., Legro, R. S., Balen, A. H., Lobo, R., . . . Laven, J. S. (2012). Consensus on women's health aspects of polycystic ovary syndrome (PCOS): the Amsterdam ESHRE/ASRMSponsored 3rd PCOS Consensus Workshop Group. Fertility and sterility, 97(1), 28-38. e25.

Gopalakrishnan, L., Doriya, K., \& Kumar, D. S. (2016). Moringa oleifera: A review on nutritive importance and its medicinal application. Food Science and Human Wellness, 5(2), 49-56.

Grubben, G. J. (2004). Plant Resources of Tropical Africa (PROTA) (Vol. 1): Prota.

Gupta, R., Mathur, M., Bajaj, V. K., Katariya, P., Yadav, S., Kamal, R., \& Gupta, R. S. (2012). Evaluation of antidiabetic and antioxidant activity of Moringa oleifera in experimental diabetes. Journal of Diabetes, 4(2), 164-171.

Homburg, R. (2003). The management of infertility associated with polycystic ovary syndrome. Reproductive Biology and Endocrinology, 1(1), 109.

Huang, Y., Sun, J., Wang, X., Tao, X., Wang, H., \& Tan, W. (2015). Asymptomatic chronic gastritis decreases metformin tolerance in patients with type 2 diabetes. Journal of clinical pharmacy and therapeutics, 40(4), 461-465.

Kabel, A. M. (2016). Polycystic ovarian syndrome: insights into pathogenesis, diagnosis, prognosis, pharmacological and nonpharmacological treatment. Pharmaceutical Bioprocessing, 4(1).

Li, R., \& Albertini, D. F. (2013). The road to maturation: somatic cell interaction and self-organization of the mammalian oocyte. Nature reviews. Molecular cell biology, 14(3), 141.

Magoffin, D. A. (2006). Ovarian Steroidogenic Abnormalities in the Polycystic Ovary Syndrome Androgen Excess Disorders in Women (pp. 203-211): Springer.

Marshall, K. (2001). Polycystic ovary syndrome: clinical considerations. Alternative Medicine Review, 6(3), 272-272.

Mukherjee, S., \& Maitra, A. (2010). Molecular \& genetic factors contributing to insulin resistance in polycystic ovary syndrome.

Rahmat, H. (2009). Identifikasi Senyawa Flavonoid Pada Sayuran Indigenous Jawa Barat. Institut Pertanian Bogor, Bogor.

Rojas, J., Chávez, M., Olivar, L., Rojas, M., Morillo, J., Mejías, J., Bermúdez, V. (2014). Polycystic ovary syndrome, insulin resistance, and obesity: navigating the pathophysiologic labyrinth. International journal of reproductive medicine, 2014.

Rusnasari, V. D. (2005). Hubungan Resistensi Insulin (Homa-Ir) dengan Obesitas dan Perubahan Hormon Androgen pada Penderita Sindroma Ovarium Polikistik. Program Pasca Sarjana Universitas Diponegoro.

Santoso, B. (2010). Management of Polycystic Ovary Syndrome in 
Adolescent. Folia Medica Indonesiana, 46(1), 66-71.

Shah, K. N., \& Patel, S. S. (2016). Phosphatidylinositide 3-kinase inhibition: A new potential target for the treatment of polycystic ovarian syndrome. Pharmaceutical biology, 54(6), 975-983.

Siregar, T., Linggi, Y., Riady, G., \& Armansyah, T. (2006). Profil titer antiserum-inhibin hasil induksi inhibin $32 \mathrm{kDa}$ pada kelinci sebagai kandidat vaksin untuk induksi superovulasi $=$ Profile of antibody titre against inhibin in rabbit following induction of inhibin 32 KDA. Jurnal Sain Veteriner, 24(1).

Sulistyorini, R., Johan, A., \& Djamiatun, K. (2015). Pengaruh Ekstrak Etanol Daun Kelor (Moringa oleifera) pada Ekspresi Insulin dan Insulitis Tikus Diabetes Melitus. Majalah Kedokteran Bandung, 47(2), 69-76.

Veterini, V., Santoso, B., \& Widjiati, W. (2015). Oxygen Hyperbaric Exposure Induces GLUT4 Expression Reduction and No Folliculogenesis Alterations in Rat PCOS with Insulin Resistance Model. Majalah Obstetri \& Ginekologi, 23(3), 112-117.

Volpi, E., Lieberman, S. A., Ferrer, D. M., Gilkison, C. R., Rasmussen, B. B., Nagamani, M., \& Urban, R. J. (2005). The relationships between testosterone, body composition, and insulin resistance. Diabetes care, 28(2), 429-432.

Wang, Z., Zhai, D., Zhang, D., Bai, L., Yao, R., Yu, J., . . . Yu, C. (2017). Quercetin Decreases Insulin Resistance in a Polycystic Ovary Syndrome Rat Model by Improving Inflammatory Microenvironment. Reproductive Sciences, 24(5), 682690.

Zeyneloglu, H. B., \& Esinler, I. (2007). Chronic complications of polycystic ovary syndrome Polycystic Ovary Syndrome (pp. 102-112): Anshan, Tunbridge Wells, UK. 